\title{
Changes in actin network during calcium-induced exocytosis in permeabilized GH3 cells: calcium directly regulates F-actin disassembly
}

\author{
M Yoneda, T Nishizaki ${ }^{1}$, K Tasaka, H Kurachi, A Miyake \\ and Y Murata
}

Department of Obstetrics and Gynecology, Osaka University Medical School, 2-2, Yamadaoka Suita Osaka, 565-0871, Japan

${ }^{1}$ Department of Obstetrics and Gynecology, Suita Municipal Hospital, Osaka, Japan

(Requests for offprints should be addressed to T Nishizaki at Department of Obstetrics and Gynecology, Suita Municipal Hospital, 2-13-20, Katayama-cho Suita Osaka, 564-0082, Japan)

\begin{abstract}
Using digitonin-permeabilized GH3 cells, we investigated both the release of prolactin (PRL) and changes in the cytoskeleton. We determined that permeabilized GH3 cells released PRL in a dose-dependent manner upon addition of micromolar $\mathrm{Ca}^{2+}$. Phalloidin, a filamentous actin (F-actin) stabilizing agent, inhibited both $\mathrm{Ca}^{2+}$ dependent and -independent PRL release, whereas cytochalasin $\mathrm{B}$, a destabilizing agent, had almost no effect on the release. Observation with a confocal laser scanning microscope revealed that F-actin existed mainly in the cortical region in the quiescent state. Increased cytosolic $\mathrm{Ca}^{2+}$ induced a change in $\mathrm{F}$-actin distribution: $\mathrm{F}$-actin in the cortical region decreased, whereas F-actin inside the
\end{abstract}

cells increased. This change in F-actin distribution was not observed when phalloidin was added. Addition of cytochalasin B induced patchy F-actin spots, but the pattern of the changes of F-actin distribution did not change. The time course of change in $\mathrm{F}$-actin distribution showed that the $\mathrm{F}$-actin network in the cortical region was reduced within $1 \mathrm{~min}$, and $\mathrm{Ca}^{2+}$-dependent release of PRL continued for up to $20 \mathrm{~min}$. These results suggest that the F-actin network near the membrane acts as a barrier to exocytosis and that $\mathrm{Ca}^{2+}$ directly controls the cytoskeletal changes.

Journal of Endocrinology (2000) 166, 677-687

\section{Introduction}

The pathway of signal transduction in exocytosis has been investigated in various cells, and it has been clarified that an increase in the cytoplasmic $\mathrm{Ca}^{2+}$ concentration is the key step in triggering exocytosis (Hutton 1986, Augustine et al. 1987). However, the precise mechanism of exocytosis resulting from increased $\mathrm{Ca}^{2+}$ remains unclear. The molecular mechanisms by which $\mathrm{Ca}^{2+}$ regulates secretory granule transport, cytoskeletal rearrangements, secretory granule-plasma membrane interaction and exocytotic fusion are now under investigation. In the 1980s, numerous reports suggested involvement of the cytoskeleton in exocytosis (Cheek et al. 1986, Trifaró 1990). In particular, the actin network was considered to be the most important part of the cytoskeleton with regard to the regulation of the traffic of secretory granules (Aunis \& Bader 1988, Segawa \& Yamashina 1989). Most of the experiments using phalloidin and cytochalasin, which induce actin fiber polymerization and depolymerization respectively, showed that depolymerization of F-actin was required for exocytosis (Lelkes et al. 1986). Therefore, it is considered that actin fibers form a network and act as a barrier to secretory granules moving towards the plasma membrane. Trifaró et al. (1992) supported this hypothesis by showing that concomitant and similar redistribution of $\mathrm{F}$-actin and scinderin, an actin filament-severing protein, occurred upon nicotinic stimulation and that the redistribution would produce subplasmalemmal areas of decreased viscosity and increased mobility of secretory granules in chromaffin cells. However, these findings are still circumstantial and it is also unknown whether depolymerization of F-actin itself is sufficient for exocytosis (Muallem et al. 1995), because the F-actin depolymerizing agents themselves, such as cytochalasin, do not induce but only potentiate exocytosis (Sontag et al. 1988).

Recent progress in the study of neurotransmitters has revealed that the final step in the regulated fusion of vesicles with the plasma membrane requires a complex that includes synaptobrevin, syntaxin and synaptosomeassociated protein of $25 \mathrm{kDa}$ (SNAP-25) (Rothman 1994). However, the final step is not clear in endocrine cells, and even the participation of these proteins is not yet clear. The precise steps in which $\mathrm{Ca}^{2+}$ regulates the traffic of 
secretory granules have not been established. Moreover, there has been no report about the relationship between this protein complex and the changes in F-actin network. Adrenal chromaffin cells have often been used in studies of the molecular mechanism of exocytosis. However, these cells have the characteristics of both endocrine cells and neurons, and do not represent endocrine cells. Only a few reports indicated a change in $\mathrm{F}$-actin distribution during stimulation of endocrine cells other than chromaffin cells (van de Moortele et al. 1991, Kiley et al. 1992, Carbajal et al. 1997), and we know of very few studies that determined both secretion of hormone and the changes in F-actin distribution at the same time (Sontag et al. 1988, van de Moortele et al. 1991, Carbajal et al. 1997).

In the present study, we used digitonin-permeabilized GH3 cells, which were derived from the rat pituitary adenoma and release prolactin (PRL), as a model of endocrine cells for examining the precise mechanisms by which $\mathrm{Ca}^{2+}$ regulates exocytosis. Permeabilization of the cells allows direct access to the cell interior and makes it easier to analyze each step in exocytosis. Using a confocal laser microscope, we analyzed the changes in the actin network quantitatively. We examined the precise relationship between the release of PRL and the changes in the cytoskeleton under the same experimental conditions.

\section{Materials and Methods}

\section{Materials}

Ham F-10 medium was purchased from Gibco Laboratories (Grand Island, NY, USA). Digitonin was obtained from Merck Laboratories (Darmstadt, Germany). All other reagents were obtained from Sigma Chemical (St Louis, MO, USA). Plastic cell-culture flasks and multiwell plates were purchased from Falcon, Becton Dickinson Labware (Oxnard, CA, USA). Glass-bottom microwell dishes coated with poly-D-lysine were obtained from MatTek Corp. (Ashland, MA, USA).

\section{Cell culture}

GH3 cells were obtained from the Japanese Cancer Research Resources Bank. The cells were fed with Ham F-10 medium supplemented with $1.2 \mathrm{~g} / 1 \mathrm{NaHCO}_{3}, 5 \%$ fetal calf serum (FCS) and $12.5 \%$ horse serum (HS), without antibiotics. They were maintained in $75 \mathrm{~cm}^{2}$ cell culture flasks at $37^{\circ} \mathrm{C}$ in an atmosphere of $5 \% \mathrm{CO}_{2}, 95 \%$ humidified air, and subcultured every 5-7 days. Two or three days before the experiments, the cells were seeded onto 24-well plates at a density of about $10^{6}$ /well for studies of PRL release or onto glass bottom microwell dishes at $0 \cdot 2 \times 10^{6} /$ well for morphological studies.

\section{Release of PRL from permeabilized GH3 cells}

The experiment on PRL release was performed according to the following procedure. GH3 cells, which were cultured on 24-well plates, were washed twice with $1 \mathrm{ml}$ Ham F-10 medium supplemented with $1 \cdot 2 \mathrm{~g} / 1 \mathrm{NaHCO}_{3}$ and $0 \cdot 1 \%$ bovine serum albumin (BSA). They were then incubated for another $30 \mathrm{~min}$ at $37^{\circ} \mathrm{C}$ in fresh medium, and washed again with the same medium. After being washed, the cells were simultaneously permeabilized and stimulated in $0.4 \mathrm{ml}$ Kglu buffer $(20 \mathrm{mM}$ potassium acetate, $120 \mathrm{mM}$ potassium glutamate, $20 \mathrm{mM}$ Hepes, $1 \mathrm{mM}$ EGTA, $5 \mathrm{mM}$ D-glucose, $0 \cdot 1 \%$ BSA, $\mathrm{pH} 7 \cdot 4$ ) containing $10 \mu \mathrm{M}$ digitonin, various doses of $\mathrm{CaCl}_{2}$ and other agents for $20 \mathrm{~min}$. The free $\mathrm{Ca}^{2+}$ concentrations were calculated as described previously (Nishizaki et al. 1992). After the incubation, buffers were aspirated into tubes on ice and centrifuged at $1000 \mathrm{~g}$ for $10 \mathrm{~min}$ at $4{ }^{\circ} \mathrm{C}$ to remove detached cells. The supernatants were collected and stored at $-20{ }^{\circ} \mathrm{C}$ until the PRL assay. The concentrations of PRL were determined by radioimmunoassay (RIA), using the agents and procedure supplied under the National Institute of Diabetes, Digestive and Kidney Disease (NIDDK) Rat Hormone Distribution Program. In this assay, the sensitivity and intra-assay coefficient of variation are $100 \mathrm{pg} /$ tube and $10 \cdot 0 \%$ respectively.

\section{F-actin staining by FITC-labeled phalloidin}

The GH3 cells in the glass-bottom microwell dishes were washed twice with $1 \mathrm{ml}$ of BSSG buffer $(5 \mathrm{mM} \mathrm{KCl}$, $142 \mathrm{mM} \quad \mathrm{NaCl}, \quad 1.5 \mathrm{mM} \quad \mathrm{MgCl}_{2} \cdot 6 \mathrm{H}_{2} \mathrm{O}, \quad 14.3 \mathrm{mM}$ $\mathrm{NaHCO}_{3}, 10 \mathrm{mM}$ Hepes, $5 \mathrm{mM}$ D-glucose, $0 \cdot 1 \mathrm{mM}$ EGTA, pH 7-2). To confirm the distribution of F-actin in quiescent state cells, the cells were fixed with cold Zamboni solution (2\% paraformaldehyde, $0 \cdot 13 \mathrm{M}$ phosphate saline buffer, $0 \cdot 21 \%$ picric acid) without stimulation. After 2 days' fixation at $4{ }^{\circ} \mathrm{C}$, cellular F-actin was stained with $1.6 \mu \mathrm{M}$ fluorescein isothiocyanate (FITC)-labeled phalloidin in Kglu buffer for $10 \mathrm{~min}$, followed by washing twice with $1 \mathrm{ml} \mathrm{Kglu}$.

In order to determine the effect of $\mathrm{Ca}^{2+}$ stimulation, cultured GH3 cells were washed twice with BSSG buffer. They were then simultaneously permeabilized and stimulated in Kglu buffer containing $10 \mu \mathrm{M}$ digitonin and $1 \mu \mathrm{M}$ free $\mathrm{Ca}^{2+}$ for $10 \mathrm{~min}$. This was followed by a wash with $1 \mathrm{ml} \mathrm{Kglu}$ without $\mathrm{Ca}^{2+}$ and digitonin. In case of fixed cells, the cells were fixed with cold Zamboni solution for at least 2 days at $4{ }^{\circ} \mathrm{C}$ and $\mathrm{F}$-actin was stained by the same procedure as for the quiescent cells. In case of live cells, immediately after washing, the cells were treated with $1.6 \mu \mathrm{M}$ FITC-labeled phalloidin in Kglu buffer for $10 \mathrm{~min}$, followed by washing twice with $1 \mathrm{ml} \mathrm{Kglu}$.

\section{Confocal laser scanning microscope}

Kglu buffer was mounted on FITC-phalloidin stained cells, and fluorescent images were obtained using a confocal laser scanning microscope system (LSM 410, Carl Zeiss Inc. Germany) at an excitation wavelength of 

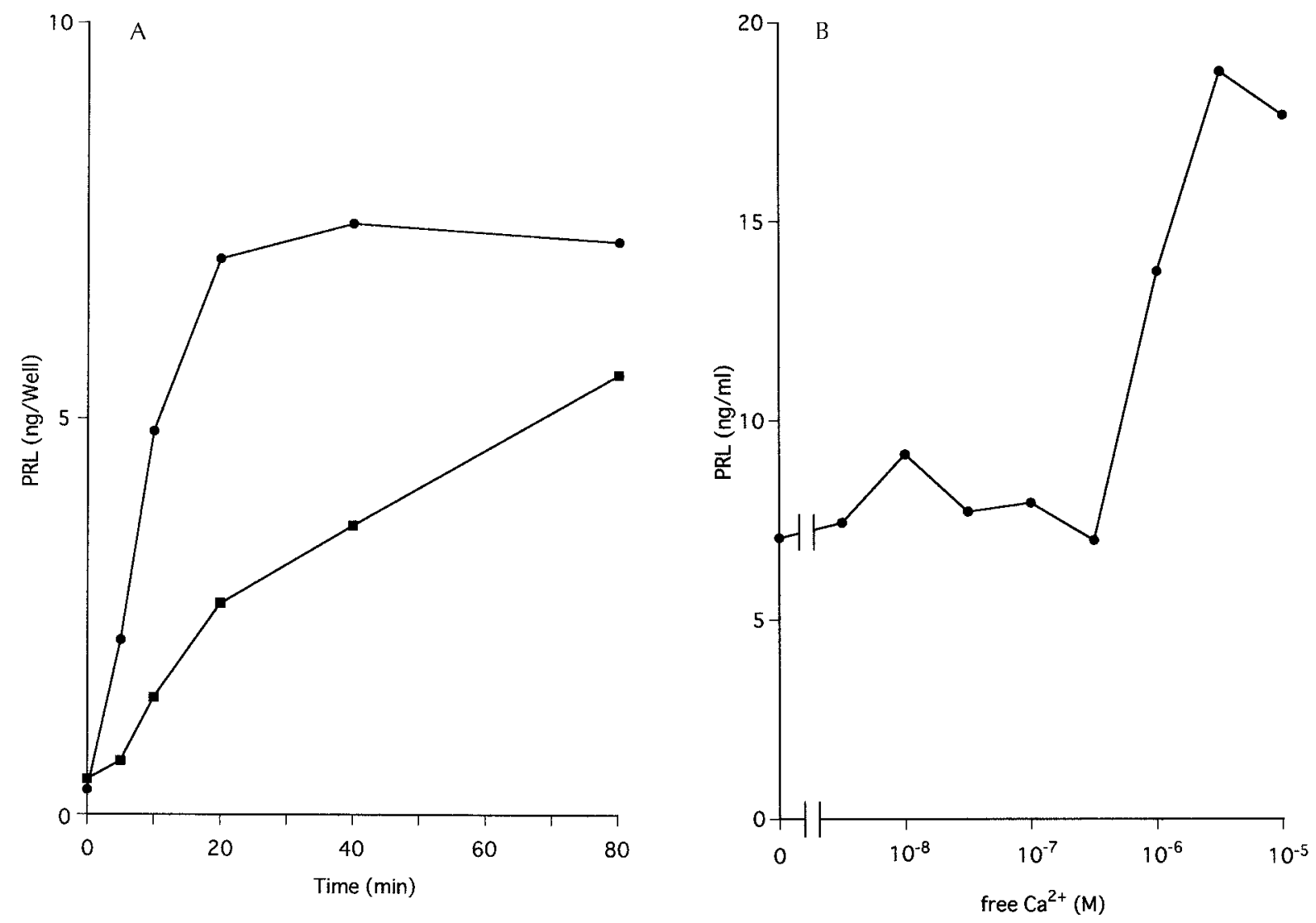

Figure 1 PRL secretion by digitonin-permeabilized GH3 cells. After three days' culture in Ham F-10 medium containing 5\% FCS and $12.5 \% \mathrm{HS}$ in 24-well culture plates, the GH3 cells were washed twice, then permeabilized and stimulated by incubation in Kglu buffer containing $10 \mu \mathrm{M}$ digitonin. (A) The time course of PRL secretion was determined for various times of incubation with (-) and without $(\boldsymbol{\square}) 1 \mu \mathrm{M}$ free $\mathrm{Ca}^{2+}$. (B) $\mathrm{Ca}^{2+}$-dependent PRL release was determined. GH3 cells were stimulated for 20 min, then the buffer was collected and centrifuged at $1000 \mathrm{~g}$ for $10 \mathrm{~min}$. The amount of PRL in the supernatant was determined by RIA.

$488 \mathrm{~nm}$ and an emission wavelength of $515 \mathrm{~nm}$. Each parameter of the confocal laser microscope was fixed in every experiment. In this condition, full-width halfmaximum (FWHM, half maximum width of optical section) was $1 \mu \mathrm{m}$. The equatorial plane of focus was defined as the midpoint between the top and the bottom of the cell; the nucleus, which does not contain F-actin, usually lies on this plane. Each image of cell was saved immediately after the observation until the analysis. To control for the effect of bleach of the fluorescence, we confirmed that averages of overall intensity of the first and last ten cells that were observed in one experiment were not different.

\section{Analysis of F-actin distribution}

Images of equatorial slices were quantified by radial line scan analysis. The fluorescence intensity of FITCphalloidin along the horizontal line that goes through the center of the cell was measured for each cell using an 'NIH image' program. The edge of the cell was defined as the beginning of the sharp slope of the intensity profile. Each value for the intensity seen at the same distance from the edge was summed and averaged to form the intensity profile for each set of experimental conditions. One pixel represents a distance of $0.0992 \mu \mathrm{m}$.

\section{Presentation of data}

All PRL release experiments and FITC-phalloidin staining experiments were carried out using at least three different cell preparations with good reproducibility. All the figures are representative; in the case of PRL release experiments, all data are given as the mean of duplicate determinations of same cell preparations.

\section{Results}

$\mathrm{Ca}^{2+}$ dependent PRL secretion from permeabilized GH3 cells

For both PC12 cells and bovine chromaffin cells, it has been established that pores formed by digitonin in plasma 

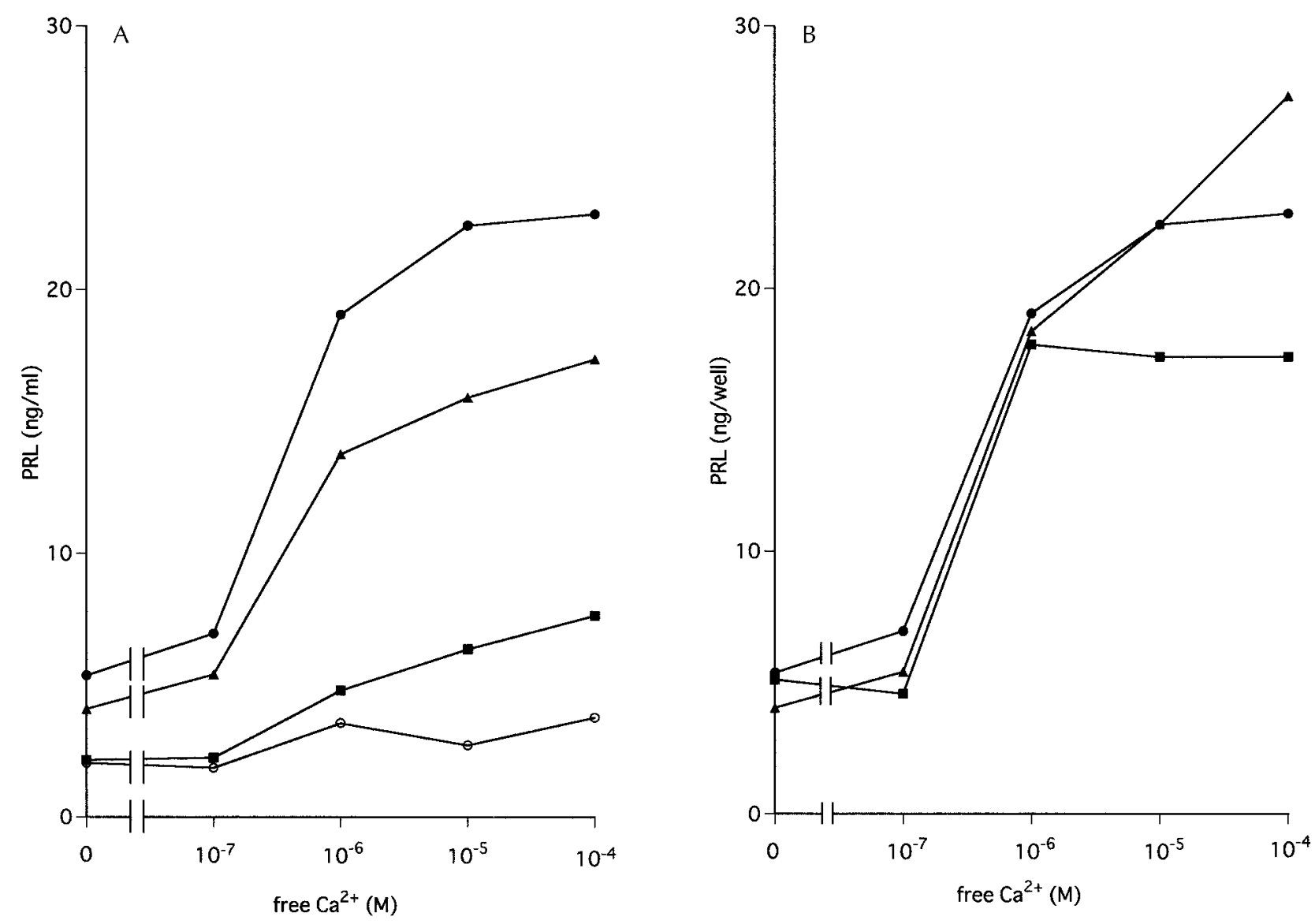

Figure 2 Effects of phalloidin and cytochalasin B on PRL secretion by permeabilized GH3 cells. (A) GH3 cells were incubated for 20 min with Kglu buffer containing $10 \mu \mathrm{M}$ digitonin, various concentrations of free $\mathrm{Ca}^{2+}$ and $0(\mathbf{O}), 1(\mathbf{\Delta}), 5(\boldsymbol{\square})$ or $10(\mathrm{O}) \mu \mathrm{M}$ phalloidin. (B) GH3 cells were incubated for 20 min with Kglu buffer containing $10 \mu \mathrm{M}$ digitonin, various concentrations of free Ca ${ }^{2+}$ and $0(\mathbf{O}), 10(\mathbf{\Delta})$ or 50 ( $\boldsymbol{\square}) \mathrm{M}$ cytochalasin B. After collection, the buffer was centrifuged at $1000 \boldsymbol{g}$ for $10 \mathrm{~min}$. The amount of PRL in the supernatant was measured by RIA.

membranes do not impair the process of exocytosis and they are large enough to allow macromolecules to pass in both directions (Schäfer et al. 1987, Holz 1988). A high-potassium buffer was used in the permeabilization experiments. We studied the effect of various concentrations of digitonin on GH3 cells (data not shown), and confirmed that $10 \mu \mathrm{M}$ digitonin was sufficient to permeabilize the cell membrane and adequately preserve $\mathrm{Ca}^{2+}$-dependent exocytosis. To examine the time course of PRL release from the permeabilized GH3 cells, GH3 cells seeded on 24-well plates were incubated for $0,5,10$, 20, 40 or $80 \mathrm{~min}$ in Kglu buffer containing $10 \mu \mathrm{M}$ digitonin with or without $1 \mu \mathrm{M}$ free $\mathrm{Ca}^{2+}$ at room temperature. As shown in Fig. 1A, PRL release from the permeabilized cells reached a plateau within $20 \mathrm{~min}$ in the presence of $\mathrm{Ca}^{2+}$. In contrast, the release increased linearly up to $80 \mathrm{~min}$ in the absence of $\mathrm{Ca}^{2+}$. This linear increase in PRL release without $\mathrm{Ca}^{2+}$ may be due to a direct effect of digitonin on secretory granules (Grant et al. 1987). The difference in PRL released in the presence and in the absence of $1 \mu \mathrm{M} \mathrm{Ca}^{2+}$ reached a maximum at $20 \mathrm{~min}$. The effect of $\mathrm{Ca}^{2+}$ concentration on PRL release after 20 min of incubation was then studied (Fig. 1B). Over the physiological $\mathrm{Ca}^{2+}$ concentration range $(0 \cdot 1-10 \mu \mathrm{M})$, PRL release was regulated by the $\mathrm{Ca}^{2+}$ concentration. Nearly the same pattern of $\mathrm{Ca}^{2+}$-dependent exocytosis was observed as in digitonin-permeabilized bovine chromaffin cells (Pocotte et al. 1985) and GH3 cells permeabilized by electric field discharge (Ronning \& Martin 1985). ATP was not included in Kglu buffer and the addition of ATP to Kglu buffer had no effect on PRL release (data not shown).

Effects of phalloidin and cytochalasin B on PRL secretion from GH3 cells

We tested the effects of two agents, which affect the equilibrium between filamentous and monomeric actin, 

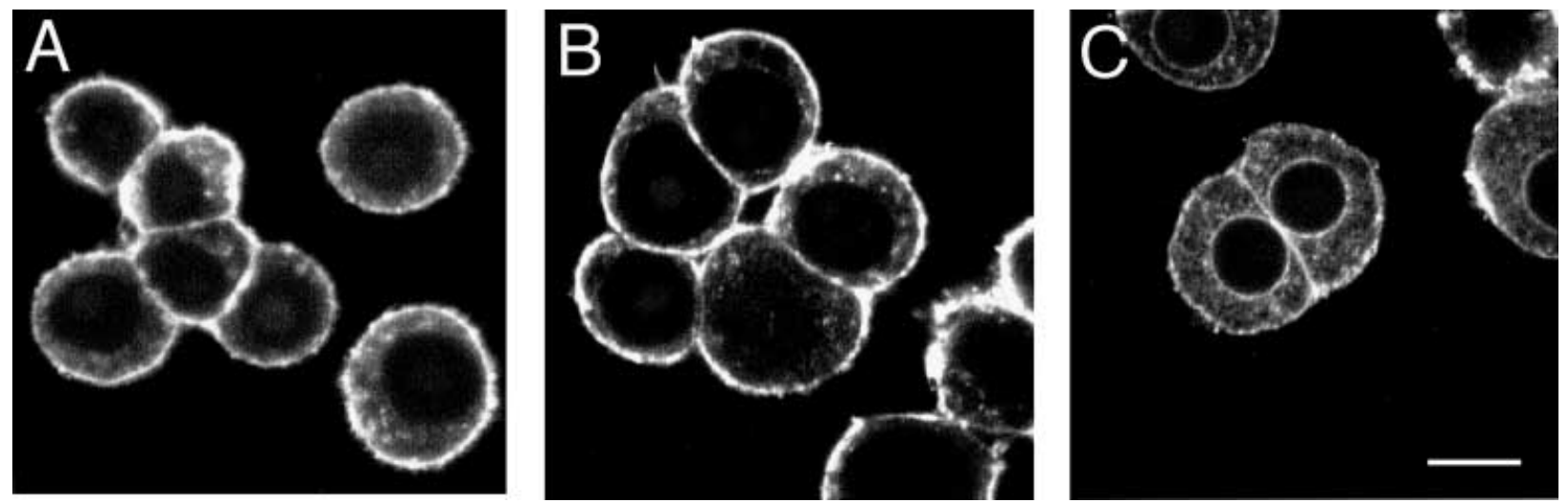

Figure 3 Confocal images of FITC-phalloidin-stained quiescent and stimulated GH3 cells fixed with Zamboni solution. GH3 cells were subcultured on glass-bottom culture dishes in Ham F-10 medium containing 5\% FCS and 12.5\% HS. After 2 days' culture, the cells were washed twice with BSSG and fixed with cold Zamboni solution (A) or permeabilized with $10 \mu \mathrm{M}$ digitonin with (C) or without (B) $1 \mu \mathrm{M}$ free $\mathrm{Ca}^{2+}$ for 10 min and fixed. After 2 days' fixation in a cold room, GH3 cells were stained with $1 \cdot 6 \mu \mathrm{M}$ FITC-labeled phalloidin and observed under a confocal laser microscope. The bar in $\mathrm{C}$ represents $10 \mu \mathrm{m}$.
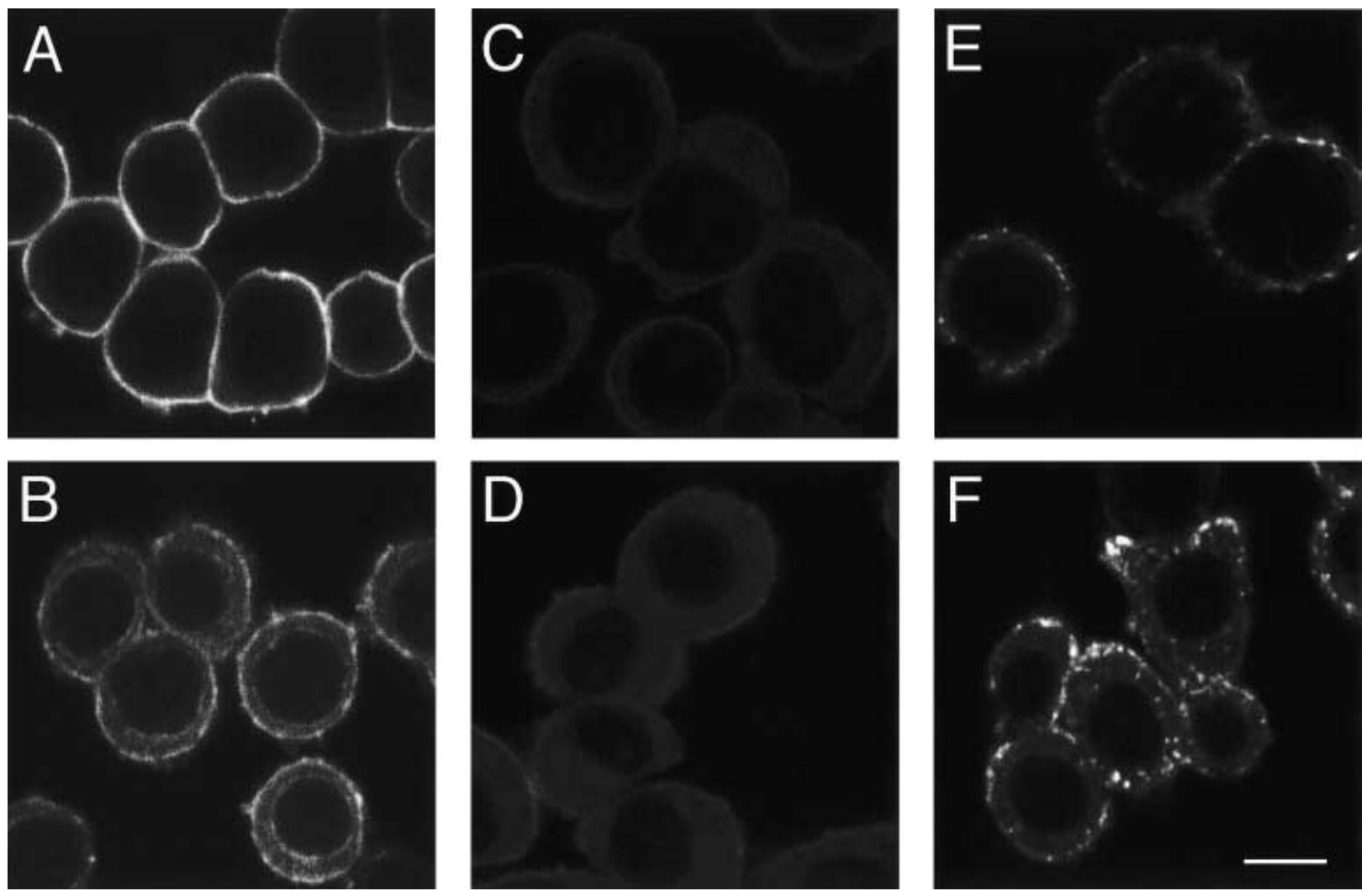

Figure 4 Confocal images of FITC-phalloidin-stained permeabilized living GH3 cells. GH3 cells were subcultured on glass-bottom culture dishes in Ham F-10 medium containing 5\% FCS and 12.5\% HS. After 2 days' culture, the cells were washed twice with BSSG and permeabilized with $10 \mu \mathrm{M}$ digitonin then left unstimulated (A, C, E) or stimulated (B, D, F) with $1 \mu \mathrm{M}$ free $\mathrm{Ca}^{2+}$ and other agents for $10 \mathrm{~min}$. Then the $\mathrm{GH} 3$ cells were stained with $1.6 \mu \mathrm{M}$ FITC-labeled phalloidin and observed under a confocal laser microscope. The permeabilization buffer contained no other agents (A and B), $5 \mu \mathrm{M}$ phalloidin (C and D) or $5 \mu \mathrm{M}$ cytochalasin $\mathrm{B}(\mathrm{E}$ and $\mathrm{F})$. The bar in $\mathrm{F}$ represents $10 \mu \mathrm{m}$. 

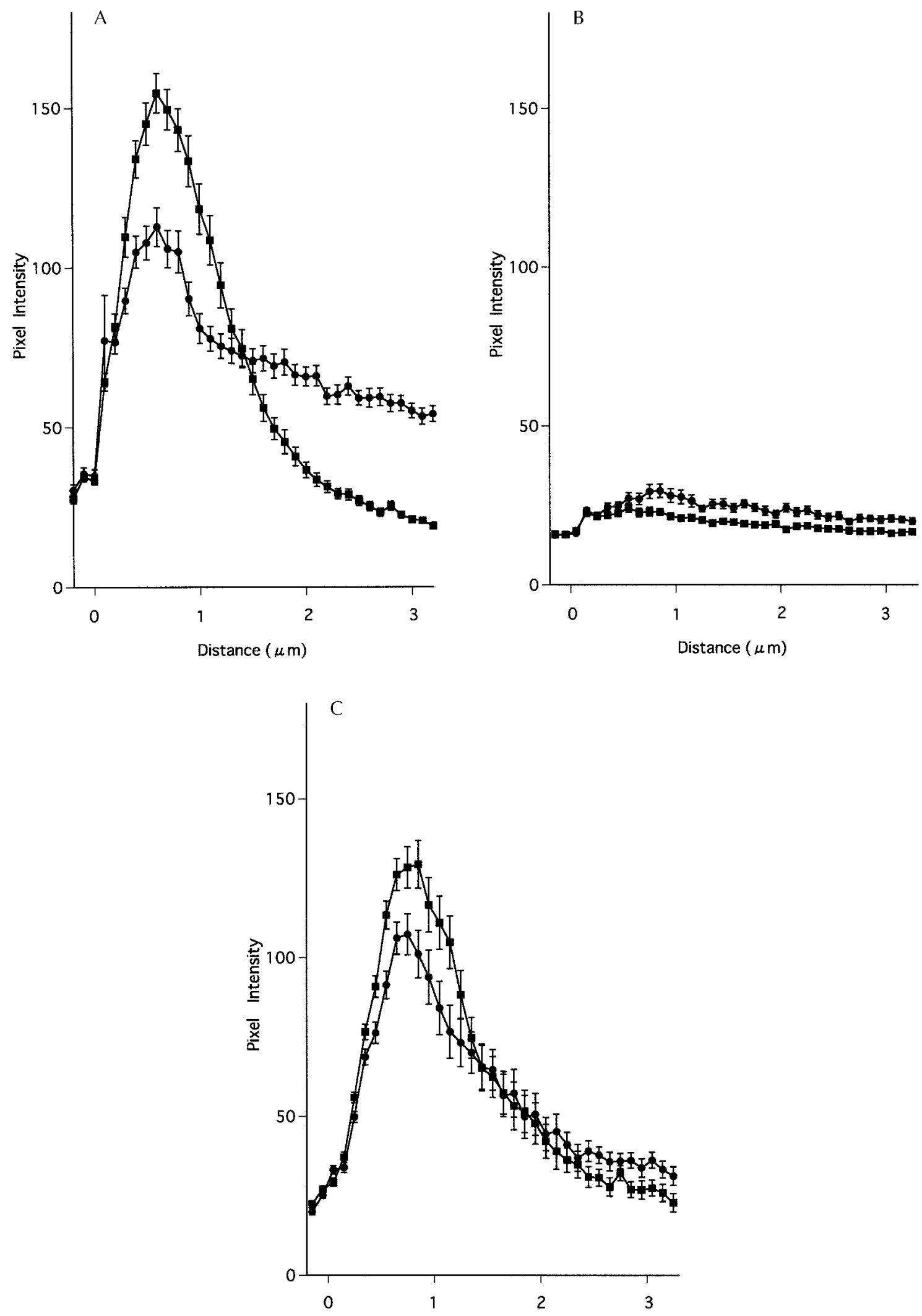
on PRL release in permeabilized GH3 cells. One to ten micromolar phalloidin, which stabilizes F-actin, was added to the buffer when GH3 cells were stimulated with various concentrations of free $\mathrm{Ca}^{2+}$. PRL secretion was suppressed by phalloidin at any concentration of $\mathrm{Ca}^{2+}$ (Fig. 2A). We also tested the effect of cytochalasin B, a microfilament-destabilizing agent that blocks the filaments' barbed ends. However, no effect of cytochalasin B on PRL release was observed except for mild suppression at high concentrations (Fig. 2B).

\section{F-actin distribution in the quiescent and $\mathrm{Ca}^{2+}$-stimulated GH3 cells}

In order to confirm the distribution of actin network in the quiescent GH3 cells, FITC-labeled phalloidin was used to stain F-actin of $\mathrm{GH} 3$ cells in microwell dishes that were fixed without any treatment. FITC-phalloidin staining of quiescent $\mathrm{GH} 3$ cells revealed F-actin to be present mainly in the cortex (Fig. 3A). Although the intensity of the cortex ring was almost homogeneous, close observation at high magnification showed weak heterogeneity in the intensity of the ring. To determine the effect of permeabilization, GH3 cells were permeabilized without or with $1 \mu \mathrm{M}$ free $\mathrm{Ca}^{2+}$ and fixed with Zamboni solution (Fig. $3 \mathrm{~B}$ and 3C respectively). There was no influence of permeabilization by digitonin on $\mathrm{F}$-actin distribution in the quiescent GH3 cells (Fig. 3A and 3B). Stimulation of permeabilized GH3 cells with $1 \mu \mathrm{M}$ free $\mathrm{Ca}^{2+}$ induced changes in F-actin distribution: the staining of the cortex region of the cell was disrupted and the overall intensity decreased, whereas the intensity of the interior region increased diffusely (Fig. 3C). To observe the change in actin network in live cells in detail, GH3 cells were stained with FITC-phalloidin without fixation immediately after permeabilization and stimulation. F-actin distributions were same as in fixed GH3 cells, except for very subtle staining in the nucleus of fixed cells (Figs 3B, 3C and 4A, 4B respectively). Up to $20 \mathrm{~min}$, incubation with digitonin had no effect on F-actin distribution in the quiescent cells (data not shown). Because phalloidin is a probe of F-actin, the decrease in FITC-phalloidin fluorescence intensity indicates disassembly of the actin network at the plasma membrane.
Quantitative analysis of changes in F-actin distribution

The changes in the Distribution of F-actin detected after stimulation of permeabilized cells were further analyzed quantitatively. Images such as those shown in Fig. 4 were quantified using radial line scan analysis of equatorial slices, as described in Materials and Methods. The FITC fluorescence intensity profiles for each set of experimental conditions were pooled. Figure 5A confirms and quantifies the effects of $1 \mu \mathrm{M}$ free $\mathrm{Ca}^{2+}$ seen in Fig. $4 \mathrm{~A}$ and $4 \mathrm{~B}$. A selective decrease and increase in the intensity of F-actin in the cortical and cytoplasmic regions respectively were demonstrated.

\section{Effect of phalloidin and cytochalasin B on F-actin distribution}

To investigate the effect of phalloidin on F-actin distribution, GH3 cells were incubated with $5 \mu \mathrm{M}$ unlabeled phalloidin along with $\mathrm{Ca}^{2+}$, and stained with FITClabeled phalloidin. Because of the competition between unlabeled $(5 \mu \mathrm{M})$ and labeled $(1.6 \mu \mathrm{M})$ phalloidin to bind to F-actin, the binding of FITC-labeled phalloidin was markedly inhibited (Fig. 4C). The effect of $\mathrm{Ca}^{2+}$ on F-actin distribution was almost free (Fig. 4D). Quantitative analysis showed only very mild increases in intensity in the interior region after $\mathrm{Ca}^{2+}$ stimulation (Fig. 5B).

Although cytochalasin B produced a markedly patchy staining intensity of $\mathrm{F}$-actin, it had a small effect on the overall change in F-actin distribution (Fig. 4E and 4F). Quantitative analysis showed that the intensity of the cortex region decreased and that of interior region increased on $\mathrm{Ca}^{2+}$ stimulation as it did with the control, but the amounts of decrease and increase in intensity were reduced (Fig. 5C).

\section{Time course of changes in F-actin distribution in $\mathrm{Ca}^{2+}$-stimulated GH3 cells}

To examine the time course of changes in F-actin distribution, GH3 cells were permeabilized and stimulated with $\mathrm{Ca}^{2+}$ for $0,1,2$ or $5 \mathrm{~min}$ and stained with FITCphalloidin. Confocal laser microscope images were analyzed by the same procedure as for Fig. 5. Within $1 \mathrm{~min}, \mathrm{~F}$-actin in the cortex region had already decreased to the same level as after $5 \mathrm{~min}$ of stimulation. In contrast,

\footnotetext{
Figure 5 Quantitative analysis of the change in F-actin distribution induced by $\mathrm{Ca}^{2+}$. Densitometric line scan analyses were performed on confocal images of FITC-phalloidin-stained GH3 cells. A horizontal scan line was obtained per cell, which extended from the exterior to the center of the cell. The intensity profiles of the lines obtained under each experimental condition were pooled to form a mean profile, as described in Materials and Methods. Data shown are the averages of the intensity of pixels. The $X$-axis represents the distance from the edge of a cell. The experimental conditions are identical to those described in Fig. 4. (A) GH3 cells were permeabilized with $10 \mu \mathrm{M}$ digitonin and stimulated with $(\mathbf{O})$ and without $(\mathbf{\square}) 1 \mu \mathrm{M}$ free $\mathrm{Ca}^{2+} ; n=55$ cells. (B) $\mathrm{GH} 3$ cells were permeabilized and incubated with $5 \mu \mathrm{M}$ phalloidin, with $(\bullet)$ and without $(\mathbf{\square}) 1 \mu \mathrm{M}$ free $\mathrm{Ca}^{2+} ; n=30$ cells. (C) GH3 cells were permeabilized and incubated with $5 \mu \mathrm{M}$ cytochalasin B, with 


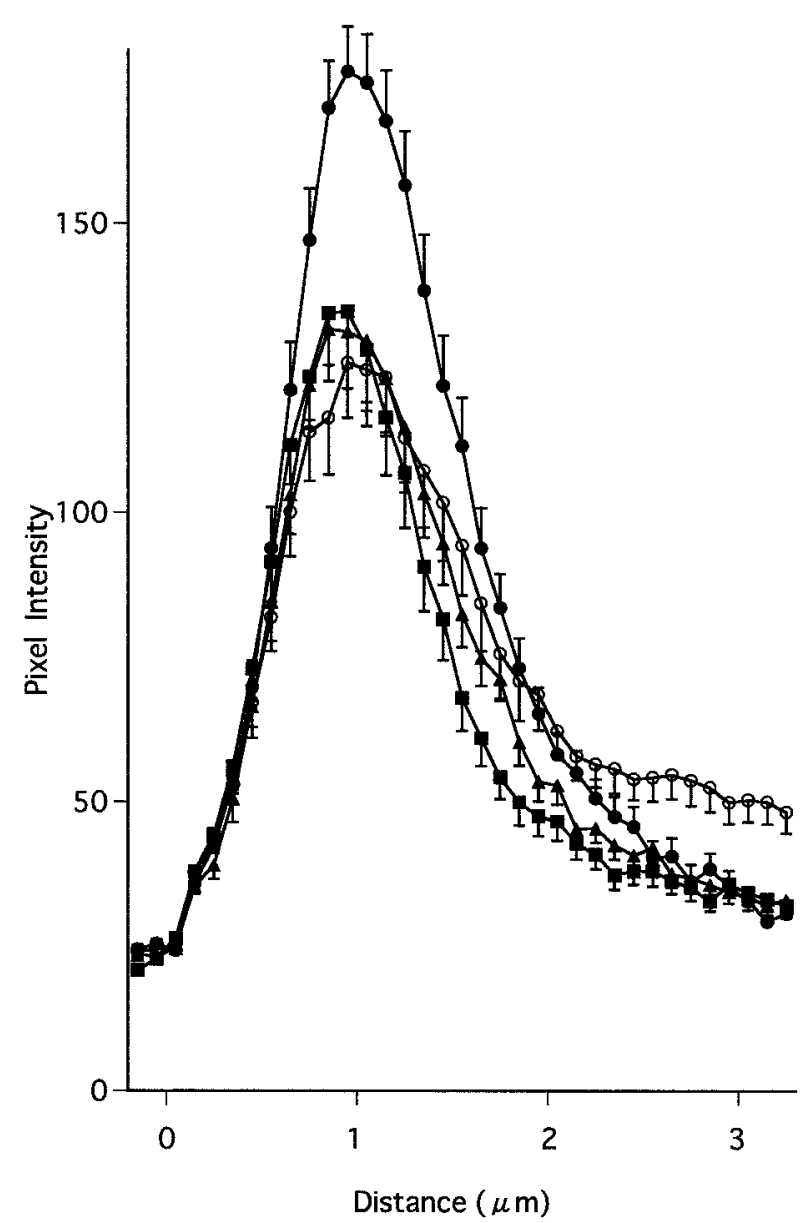

Figure 6 Time-dependent changes in F-actin distribution in $\mathrm{Ca}^{2+}$-stimulated $\mathrm{GH} 3$ cells. $\mathrm{GH} 3$ cells, which were cultured in glass-bottom culture dishes, were incubated with $10 \mu \mathrm{M}$ digitonin and $1 \mu \mathrm{M} \mathrm{Ca}^{2+}$ for $0(\mathbf{O}), 1(\boldsymbol{\Delta}), 2(\mathbf{\square})$ or $5(\bigcirc) \mathrm{min}$, and then incubated with FITC-phalloidin after washing. Confocal laser microscope images were subjected to densitometric line scan analysis. A horizontal scan line was obtained per cell, which extended from the exterior to the center of the cell. The intensity profiles of these lines for each incubation time were pooled to form a mean profile; $n=40$ cells for each incubation time. Data shown are the averages of the intensity of pixels. The $X$-axis represents the distance from the edge of a cell. Values are means + or - S.E.M.

$\mathrm{F}$-actin in the interior region did not change until $5 \mathrm{~min}$, and then increased slowly (Fig. 6).

\section{Discussion}

In neuroendocrine cells, it has been established that stimulation induces an increase in the cytosolic $\mathrm{Ca}^{2+}$, which triggers exocytosis. Many agents, such as protein kinase C (Burgoyne et al. 1989, Nishizaki et al. 1992), calmodulin (Burgoyne 1991, Cheek 1991), fodrin
(Burgoyne \& Cheek 1987, Perrin et al. 1987), gelsolin (Bader et al. 1986, Trifaró \& Vitale 1993), scinderin (Rodríguez et al. 1990, Vitale et al. 1995), calpactin (Burgoyne et al. 1991), and 14-3-3 proteins (Roth \& Burgoyne 1995) and GTP-binding proteins (Norman et al. 1994, Price et al. 1995), have been studied as $\mathrm{Ca}^{2+}$ target proteins in the regulation of exocytosis, though the exact mechanisms by which $\mathrm{Ca}^{2+}$ regulates exocytosis remain unclear. Immunocytochemical studies showed that the cortical actin network was disassembled upon nicotine stimulation of bovine adrenal chromaffin cells (Cheek \& Burgoyne 1986, Trifaró \& Vitale 1993). However, it remains controversial whether or not the disassembly of actin filaments is essential for exocytosis, and the exact relationship between the increase in cytosolic $\mathrm{Ca}^{2+}$ and actin network disassembly has not been well documented. To our knowledge, only one report has shown that increased cytosolic $\mathrm{Ca}^{2+}$ directly induced catecholamine release and the morphological change in $\mathrm{F}$-actin distribution; that study used streptolysin-O-permeabilized chromaffin cells and rhodamine-phalloidin (Sontag et al. 1988). Permeabilization of the cells made it easier to control the cytosolic $\mathrm{Ca}^{2+}$ concentration directly without changing any other components of the cells. In this report, we investigated more specifically the direct effects of an increase in cytosolic $\mathrm{Ca}^{2+}$ on both exocytosis and the change in F-actin distribution under the same experimental conditions. We determined the time course minutely and studied the effect of $\mathrm{Ca}^{2+}$ on the release of hormone and the change in the actin network. A confocal microscope made it possible to analyze the changes in the actin network quantitatively.

GH3 cells were permeabilized with the detergent digitonin, and we confirmed that free $\mathrm{Ca}^{2+}$ in micromolar concentrations directly induced exocytosis of PRL without requiring any co-factor. Immunofluorescence and cytochemical studies demonstrated that F-actin is localized mainly in the cortical region of chromaffin cells (Vitale et al. 1991, 1995) or mast cells (Koffer et al. 1990) in the resting state. In the case of cultured normal anterior pituitary cells (Carbajal \& Vitale 1997) and pituitaryderived GH4C1 cells (Kiley et al. 1992), these cells exhibited bright cortical actin staining, but in GH3B6 cells, the staining was diffuse in the cytoplasm and displayed a patchy aspect at the cell periphery (van de Moortele et al. 1991). The GH3 cells in our experiments showed a staining pattern similar to those of chromaffin cells and $\mathrm{GH} 4 \mathrm{C} 1$ cells.

The changes in the cytoskeleton during cell stimulation have been studied using a variety of cells, such as adrenal chromaffin cells (Zhang et al. 1995), mast cells (Norman et al. 1994), leukemia cells (Pfeiffer et al. 1985) and pancreatic acinar cells (Muallem et al. 1995). F-actin network disassembly has been observed in these cells upon stimulation. Classically, pituitary cells have been widely used for studies of the mechanisms of hormone secretion, 
and the effect of cytochalasin has been investigated (Liu \& Jackson 1986). However, only a few reports have shown changes in the cytoskeletons of pituitary cells during cell excitation (van de Moortele et al. 1991, Kiley et al. 1992, Carbajal \& Vitale 1997). The changes in F-actin distribution during thyrotropin-releasing hormone $(\mathrm{TRH})-$ or $\mathrm{K}^{+}$-induced stimulation of $\mathrm{GH} 3$-derived cells were not identical in those reports. In GH3B6 cells, thick actin bundles were formed in the cytoplasm and ran parallel to the cell surface after stimulation with TRH. In contrast, in GH4C1 cells, TRH caused a generalized decrease in fluorescence intensity, and $\mathrm{K}^{+}$did not alter the F-actin network.

Our present findings of a change in F-actin distribution - a reduction in F-actin in the cortical region and an increase in $\mathrm{F}$-actin in the interior region - have also been observed in mast cells and adrenal chromaffin cells (Norman et al. 1994, Vitale et al. 1995). This change in F-actin was different from the changes observed in both GH4C1 cells and GH3C6 cells. The reduction in the cortical F-actin network is completed within 1 min, followed by the increase in F-actin in the cytoplasm a few minutes later (Fig. 6). Because of this time lag between the decrease in F-actin in the cortex and the increase in the cell interior, the change in F-actin distribution could not be explained solely by the simple relocation of F-actin. In mast cells, it was demonstrated by two-step staining that both de novo polymerization of actin and relocation of $\mathrm{F}$-actin contributed to the increase in the internal staining (Norman et al. 1994). In our experiments, cytochalasin B reduced both the decrease in cortical $\mathrm{F}$-actin and the increase in the cell interior (Fig. 5C). This result also suggests that the increase in F-actin in the cell interior is due to de novo polymerization, and that cytochalasin $\mathrm{B}$ suppresses this polymerization. Compared with the time course of PRL release (Fig. 1A), the reduction in the cortical F-actin network was quicker. These observations support the hypothesis that disassembly of the actin network removes the barrier to secretory granule traffic towards the plasma membrane and that granules freely dock and fuse with the plasma membrane to complete exocytosis. Electron microscopic studies (Senda et al. 1989, 1994, Nakata et al. 1992, Tchakarov et al. 1998) revealed the localization of F-actin and secretory granules in chromaffin and pituitary cells: the subcortical actin filaments are distributed unevenly near the plasma membrane, and secretory granules are preferentially seen in the region where actin filaments are sparse. These findings were consistent with our present observations and provide morphlological support for the concept of the role of actin filaments.

Effects of phalloidin, which is known to bind to F-actin more tightly than to globular actin (G-actin) and shifts the equilibrium between filaments and monomers toward the filaments (Cooper 1987), were observed in both secretion and distribution changes in F-actin. Phalloidin completely inhibited $\mathrm{Ca}^{2+}$-induced release and inhibited $\mathrm{Ca}^{2+}$ independent constitutive secretion of PRL (Fig. 2A). In fluorescence studies, phalloidin itself competed with FITC-labeled phalloidin to bind with F-actin, so the staining with FITC-phalloidin decreased, but we observed no change in $\mathrm{F}$-actin distribution upon $\mathrm{Ca}^{2+}$ stimulation without a very mild increase in the interior region (Fig. $5 B)$. Because of the weak staining of the cortex of unstimulated cells, it was hard to show the difference between $\mathrm{Ca}^{2+}$-stimulated and -unstimulated cells. These results are also in agreement with the idea that the actin network acts as a barrier to the traffic of secretory granules - that is, phalloidin blocks the depolymerization of actin filaments so that the actin network is preserved and inhibits the traffic of granules and exocytosis of PRL. In contrast, cytochalasin $\mathrm{B}$, which binds to the barbed end of the actin filaments and inhibits both polymerization and depolymerization of the end of the filaments, has no effect on $\mathrm{Ca}^{2+}$-induced secretion (Fig. 2B) or the overall distribution of $\mathrm{F}$-actin in the quiescent state (Fig. 5C), although the cortical $\mathrm{F}$-actin ring was more heterogeneous (Fig. 4E). On Ca ${ }^{2+}$ stimulation, distribution of F-actin to the interior region and a punctate staining pattern of F-actin were observed (Fig. 4F). The effect of cytochalasin on hormone secretion was not identical with all cell types and experimental conditions. In the experiments on permeabilized adrenal chromaffin cells, cytochalasins usually potentiated calcium-induced secretion (Lelkes et al. 1986, Aunis \& Bader 1988, Sontag et al. 1988). However, Roth \& Burgoyne (1995), who also used digitoninpermeabilized chromaffin cells, reported that cytochalasin had no effect on basal or stimulated catecholamine secretion. We have no reasonable explanation for these differences in the effects of cytochalasin on secretion. Sontag et al. (1988) reported the effect of cytochalasin on F-actin distribution upon stimulation of chromaffin cells, and they also observed a punctate staining pattern, but what they meant by a 'punctate staining pattern' is unclear.

In the present study, we clarified the direct effect of an increase in cytosolic $\mathrm{Ca}^{2+}$ on both exocytosis and the change in the cytoskeletal actin network. Our results support the hypothesis that $\mathrm{Ca}^{2+}$ directly regulates the F-actin network, which acts as a physical barrier preventing secretory granule traffic towards the plasma membrane. A variety of proteins have been proposed as target proteins of $\mathrm{Ca}^{2+}$, but the exact relationships among these proteins are unknown. A recent study showed two stages of exocytosis: an ATP-dependent priming reaction and a $\mathrm{Ca}^{2+}$-triggered fusion reaction (Hay \& Martin 1992). As in the case of synapse of neurons, it is suggested that neuroendocrine cells also require an $\mathrm{N}$-ethylmaleimide sensitive factor (NSF)-soluble NSF attachment protein (SNAP)-SNAP receptor (SNARE) complex and $\mathrm{Ca}^{2+}$ to trigger fusion of secretory vesicles and the plasma membrane (Banerjee et al. 1996). Our results support the 
hypothesis that, in the exocytotic reaction, disassembly of the actin network and docking and fusion of secretory granules are separate steps, and $\mathrm{Ca}^{2+}$ is required for both steps. Actin network disassembly may be insufficient for exocytosis. Disassembly of the actin network allows the secretory granules to move freely, but exocytosis does not occur because the docking and fusion steps are dependent on $\mathrm{Ca}^{2+}$. Our findings that phalloidin blocked both exocytosis and the change in the actin network in spite of an increase in $\mathrm{Ca}^{2+}$ support the hypothesis that actin network disassembly is essential for exocytosis. Further investigations are necessary to clarify more precisely the mechanism and proteins that are regulated by $\mathrm{Ca}^{2+}$.

\section{References}

Augustine GJ, Charlton MP \& Smith SJ 1987 Calcium action in synaptic transmitter release. Annual Review of Neuroscience $\mathbf{1 0}$ 633-693.

Aunis D \& Bader MF 1988 The cytoskeleton as a barrier to exocytosis in secretory cells. Journal of Experimental Biology 139 253-266.

Bader MF, Trifaró JM, Langley OK, Thiersé D \& Aunis D 1986 Secretory cell actin-binding proteins: identification of a gelsolin-like protein in chromaffin cells. Journal of Cell Biology 102 636-646.

Banerjee A, Barry VA, DasGupta BR \& Martin TFJ 1996 N-Ethylmaleimide-sensitive factor acts at a prefusion ATPdependent step in $\mathrm{Ca}^{2+}$-activated exocytosis. Journal of Biological Chemistry $27120223-20226$.

Burgoyne RD 1991 Control of exocytosis in adrenal chromaffin cells. Biochimica et Biophysica Acta 1071 174-202.

Burgoyne RD \& Cheek TR 1987 Cytoskeleton: role of fodrin in secretion (news). Nature 326448.

Burgoyne RD, Morgan A \& O'Sullivan AJ 1989 The control of cytoskeletal actin and exocytosis in intact and permeabilized adrenal chromaffin cells: role of calcium and protein kinase C. Cellular Signalling 1 323-334.

Burgoyne RD, Handel SE, Morgan A, Rennison ME, Turner MD \& Wilde CJ 1991 Calcium, the cytoskeleton and calpactin (annexin II) in exocytotic secretion from adrenal chromaffin and mammary epithelial cells. Biochemical Society Transactions 19 1085-1090.

Carbajal ME \& Vitale ML 1997 The cortical actin cytoskeleton of lactotropes as an intracellular target for the control of prolactin secretion. Endocrinology 138 5374-5384.

Cheek TR 1991 Calcium signalling and the triggering of secretion in adrenal chromaffin cells. Pharmacology and Therapentics 52 173-189.

Cheek TR \& Burgoyne RD 1986 Nicotine-evoked disassembly of cortical actin filaments in adrenal chromaffin cells. FEBS Letters 207 110-114.

Cooper JA 1987 Effects of cytochalasin and phalloidin on actin. Journal of Cell Biology 105 1473-1478.

Grant NJ, Aunis D \& Bader MF 1987 Morphology and secretory activity of digitonin- and alpha-toxin-permeabilized chromaffin cells. Neuroscience 23 1143-1155.

Hay JC \& Martin TFJ 1992 Resolution of regulated secretion into sequential MgATP-dependent and calcium-dependent stages mediated by distinct cytosolic proteins. Journal of Cell Biology 119 139-151.

Holz RW 1988 Control of exocytosis from adrenal chromaffin cells. Cellular and Molecular Neurobiology 8 259-268.

Hutton JC 1986 Calcium-binding proteins and secretion. Cell Calcium 7 339-352.

Kiley SC, Parker PJ, Fabbro D \& Jaken S 1992 Hormone- and phorbol ester-activated protein kinase $\mathrm{C}$ isozymes mediate a reorganization of the actin cytoskeleton associated with prolactin secretion in GH4C1 cells. Molecular Endocrinology 6 120-131.

Koffer A, Tatham PE \& Gomperts BD 1990 Changes in the state of actin during the exocytotic reaction of permeabilized rat mast cells. Journal of Cell Biology 111 919-927.

Lelkes PI, Friedman JE, Rosenheck K \& Oplatka A 1986 Destabilization of actin filaments as a requirement for the secretion of catecholamines from permeabilized chromaffin cells. FEBS Letters 208 357-363.

Liu TC \& Jackson GL 1986 Synthesis and release of luteinizing hormone by rat anterior pituitary cells: effects of cytochalasins B and D. Endocrinology 119 236-243.

van de Moortele S, Rosenbaum E, Tixier Vidal A \& Tougard C 1991 Rapid and transient reorganization of the cytoskeleton in GH3B6 cells during short-term exposure to thyroliberin. Journal of Cell Science 99 79-89.

Muallem S, Kwiatkowska K, Xu X \& Yin HL 1995 Actin filament disassembly is a sufficient final trigger for exocytosis in nonexcitable cells. Journal of Cell Biology 128 589-598.

Nakata T \& Hirokawa N 1992 Organization of cortical cytoskeleton of cultured chromaffin cells and involvement in secretion as revealed by quick-freeze, deep-etching, and double-label immunoelectron microscopy. Journal of Neuroscience 12 2186-2197.

Nishizaki T, Walent JH, Kowalchyk JA \& Martin TFJ 1992 A key role for a $145-\mathrm{kDa}$ cytosolic protein in the stimulation of $\mathrm{Ca}^{2+}-$ dependent secretion by protein kinase C. Journal of Biological Chemistry 267 23972-23981.

Norman JC, Price LS, Ridley AJ, Hall A \& Koffer A 1994 Actin filament organization in activated mast cells is regulated by heterotrimeric and small GTP-binding proteins. Journal of Cell Biology 126 1005-1015.

Perrin D, Langley OK \& Aunis D 1987 Anti-a-fodrin inhibits secretion from permeabilized chromaffin cells. Nature 326 498-501.

Pfeiffer JR, Seagrave JC, Davis BH, Deanin GG \& Oliver JM 1985 Membrane and cytoskeletal changes associated with IgE-mediated serotonin release from rat basophilic leukemia cells. Journal of Cell Biology 101 2145-2155.

Pocotte SL, Frye RA, Senter RA, TerBush DR, Lee SA \& Holz RW 1985 Effects of phorbol ester on catecholamine secretion and protein phosphorylation in adrenal medullary cell cultures. PNAS 82 930-934.

Price LS, Norman JC, Ridley AJ \& Koffer A 1995 The small GTPases Rac and Rho as regulators of secretion in mast cells. Current Biology 5 68-73.

Rodríguez DCA, Lemaire S, Tchakarov L, Jeyapragasan M, Doucet JP, Vitale ML \& Trifaró JM 1990 Chromaffin cell scinderin, a novel calcium-dependent actin filament-severing protein. EMBO Journal 9 43-52.

Ronning SA \& Martin TFJ 1985 Prolactin secretion in permeable GH3 pituitary cells is stimulated by $\mathrm{Ca}^{2+}$ and protein kinase C activators. Biochemical and Biophysical Research Communications 130 524-532.

Roth D \& Burgoyne RD 1995 Stimulation of catecholamine secretion from adrenal chromaffin cells by $14-3-3$ proteins is due to reorganisation of the cortical actin network. FEBS Letters 374 $77-81$.

Rothman JE 1994 Mechanisms of intracellular protein transport. Nature 372 55-63.

Schäfer T, Karli UO, Gratwohl EK, Schweizer FE \& Burger MM 1987 Digitonin-permeabilized cells are exocytosis competent. Journal of Neurochemistry 49 1697-1707.

Segawa A \& Yamashina S 1989 Roles of microfilaments in exocytosis: a new hypothesis. Cell Structure and Function 14 531-544.

Senda T, Fujita H, Ban T, Zhong C, Ishimura K, Kanda K \& Sobue K 1989 Ultrastructural and immunocytochemical studies on the cytoskeleton in the anterior pituitary of rats, with special regard to 
the relationship between actin filaments and secretory granules. Cell and Tissue Research 258 25-30.

Senda T, Okabe T, Matsuda M \& Fujita H 1994 Quick-freeze, deepetch visualization of exocytosis in anterior pituitary secretory cells: localization and possible roles of actin and annexin II. Cell and Tissue Research 277 51-60.

Sontag JM, Aunis D \& Bader MF 1988 Peripheral actin filaments control calcium-mediated catecholamine release from streptolysin-Opermeabilized chromaffin cells. European Journal of Cell Biology 46 316-326.

Tchakarov LE, Zhang L, Rosé SD, Tang R \& Trifaró JM 1998 Light and electron microscopic study of changes in the organization of the cortical actin cytoskeleton during chromaffin cell secretion. Journal of Histochemistry and Cytochemistry 46 193-203.

Trifaró JM 1990 The 1989 Upjohn Award lecture. Cellular and molecular mechanisms in hormone and neurotransmitter secretion. Canadian Journal of Physiology and Pharmacology 68 $1-16$.

Trifaró JM \& Vitale ML 1993 Cytoskeleton dynamics during neurotransmitter release. Trends in Neurosciences 16 466-472.
Trifaró JM, Rodríguez del Castillo A \& Vitale ML 1992 Dynamic changes in chromaffin cell cytoskeleton as prelude to exocytosis. Molecular Neurobiology 6 339-358.

Vitale ML, Rodríguez DCA, Tchakarov L \& Trifaró JM 1991 Cortical filamentous actin disassembly and scinderin redistribution during chromaffin cell stimulation precede exocytosis, a phenomenon not exhibited by gelsolin. Journal of Cell Biology 113 1057-1067.

Vitale ML, Seward EP \& Trifaró JM 1995 Chromaffin cell cortical actin network dynamics control the size of the release-ready vesicle pool and the initial rate of exocytosis. Neuron 14 353-363.

Zhang L, Rodríguez DCA \& Trifaró JM 1995 Histamine-evoked chromaffin cell scinderin redistribution, F-actin disassembly, and secretion: in the absence of cortical F-actin disassembly, an increase in intracellular $\mathrm{Ca}^{2+}$ fails to trigger exocytosis. Journal of Neurochemistry 65 1297-1308.

Received 6 January 2000

Accepted 2 May 2000 